\author{
N. M. Mosina \\ N. V. Kazaeva
}

SEMANTICS OF VISUAL PERCEPTION VERBS
IN THE ERZYA-MORDVIN AND FINNISH LANGUAGES

The subject of this paper is visual perception verbs in the Erzya-Mordvin and Finnish languages from the point of view of their semantic characteristics in comparison. Depending on the leading role of the sensory system, which, along with the visual system, plays a major role in perception, one distinguishes between auditory, tactile, olfactory and gustatory perception. This verbal group has a sensuous level of interrelations. Being verbs of perception, they are aimed at objects that have physical characteristics, whereas many of them are focused on the perception of concepts. In this regard, the verbs of perception develop a polysemy that goes in different directions. The novelty of the research lies in the comparative study of the lexical level of the Erzya-Mordvin and Finnish languages, which will allow us to tackle some theoretic aspects of Finno-Ugric linguistics in the future. The problem associated with the study of the semantics of perception verbs, or perceptual activity, is of relevance.

Therefore, the purpose of this research is to describe the structure of the semantic field of verbs of one aspect of perception, namely the visual one: to determine the nuclear and peripheral verbal units using the material of the languages under study; to describe the system of meanings of verbal lexemes in the Erzya and Finnish languages, to analyze the polysemy of the studied verbal group in each of the above languages; to reveal additional semantic connotations in verbal lexemes; of particular interest is also the comparative study of the specifics of expression of the same semantic meaning in the context of far-related languages, in this case, Erzya and Finnish.

Keywords: Visual Perception Verbs, Semantics, Comparative Analysis, Erzya Language, Finnish Language

\title{
Introduction
}

Perception and thinking are important components of human brain activity. These two concepts are inseparably intertwined at both psychological and linguistic levels. Individuals perceive the world through their activity, communication, and imagination, thus satisfying their needs. Perception, thinking and language serve as tools for understanding the world. Perception is the most important ability of a person to get to know the surrounding reality. It is inseparably intertwined with human's mental activity, which allows one not only to distinguish objects and phenomena of the external world, but also to form its images, to be aware of what is perceived, and to reveal its properties.

The very activity of the brain depends on the interaction of individuals with the outside world, on the correlation of their activity with conditions of their life and needs. The brain is just an organ of mental activity; the person is its subject. Feelings, as well as human thoughts, originate in the brain, but it is not the brain that loves and hates, cognizes and changes the world, it is a human being that does it. Feelings and thoughts express the person's emotional and cognitive attitude to the world. 
Mental phenomena arise in the process of human interaction with the world, they are included in this interaction as a necessary component [Rubinstein 1957].

Individuals' perception of the world and the surrounding reality, as their most significant types of activity, is undoubtedly of interest to psychology, philosophy, linguistics, literary studies and other sciences. There are a large number of definitions of the concept of "perception", developed within the framework of selected disciplines. Perception is a living, active interaction with the world, with the environment, essential in adapting a person to the environment and in his/her survival [Kubryakova et al. 1997]. Perception is a living indissoluble connection of individuals with the surrounding reality, thus playing a significant role in various types of their activity: mental, behavioral, speech, emotional, etc. [Chafe 1983; Neisser 1981; Kubryakova 1999]. Perception is the most important of the functions of the human higher nervous activity, engaging another, no less important one, - thinking [Glinka $2003,6]$. Perception is a form of sensory reflection of reality in human consciousness, the ability to detect, accept, distinguish and assimilate phenomena of the external world and form its images ]Moiseeva 2005, 19]. Based on the above, the process of perception has a subjective character: a person, although unable to influence the course of events that he or she perceives, but singles out from it what he or she wants to see, hear, touch; processing and interpretation of the received information occurs on an individual basis.

Verbs are, undoubtedly, the most important domain of language, where the main mechanisms and results of perception are verbalized and interpreted. According to semantic classification, verb forms can be divided into two classes: 1) predicate verbs: causative, modal, aspect, temporal, taxis, phase, and 2) modus verbs: speech, thought, memory, knowledge, emotion, sensation, representation, perception, evaluation [Moiseeva 2005, 69]. Given the above classification, verbs of sensory perception belong to the second group. They are specific structures that carry a variety of information about the objects of surrounding reality; they not only call the objects of reality, but also convey information about the psychoemotional state and emotional relationship to the subject of speech.

Verbs of perception fill in the gaps in the lexical system of the language, which cannot fully denote all sides of reality apprehended by man, and are in many cases the only denotives of properties, processes, states, situations, without which a comprehensive existence is not possible. Perception determines a person's complex, mental and analytical life activity associated with comprehension of objects and phenomena of the surrounding reality following their direct impact on the human's senses. Depending on the leading role of the sensory system, which plays a major role in perception, there are visual, auditory, tactile, olfactory and gustatory perceptions. Since human perception is related to thinking, and conscious perception of an object or phenomenon is its mental denotation, its generalization in a word, and depending on sensitivity system in question one should distinguish verbs of visual and auditory perception, tactile verbs, verbs of olfaction and gustation.

\section{Methodical Framework}

The research into the nature and specifics of the semantics of perception verbs can be attributed to one of the most complicated and challenging problems developed in the modern philology, and still causing a great deal of debate. Apart from perception criterion, a group of sensory verbs is classified basing on the meaning "the subject's ability to perceive", which can be contrasted against the scale of non-purposefulness / purposefulness of the process [Peshkovsky 1956, 79]. In this paper we draw on the method of typological research of verbs of perception conducted by A. Viberg on the material of several languages and on his classification [Viberg 1984; 2001]. Further on, this method was successfully applied by the Finnish linguist T. Huumo on the material of the Finnish language, which made it possible to present sensory verbs as a three-level system, with account of their characteristic semantic features [Huumo 2006].

Methodologically this research draws on the works of foreign and domestic scientists devoted to the study of the general issues of category of perception and thinking [Vasil'ev 1981; Chafe 1983; Gak 1993; Kubryakova 2004], problems of classification and semantic characteristics of the verbs of perception described on the material of one language [Arkhipova 2000; Yakubova 1988; Glinka 2003; 
Karandashova 2003; Mosina 2013; 2019; Huumo 2005; 2006], as well as on the linguistic material from two or more languages [Moiseeva 2005; Prokhorova 2013; Garipova 2013; Budantseva 2014; Kaksin Chertykova 2009; Kozmach 2020; Viberg 1984, 2001].

The material for this study reaches verbal lexemes that have visual perception semantics in the modern Erzya and Finnish languages, taken from the modern explanatory dictionaries of the Erzya and Finnish languages. The analysis of polysemy and various semantic connotations of this verb group was made using the linguistic and text materials presented as examples derived from the Erzya and Finnish languages. We used the continuous sampling method in choosing examples from the fine literature in the Erzya and Finnish languages, as well as from the Korp and MokshEr linguistic corpora, containing texts on various topics and of functional style [Korp, MokshEr].

The main research methods used in this paper are methods of descriptive and component analysis, and taking into account the involvement of the two related languages, Erzya and Finnish, it was necessary to use the technique of the comparative analysis.

\section{Results}

We perceive the world through our senses. Our sensory system determines what things we perceive and how we perceive them, what attracts our attention and what is left behind. Feelings can be grouped, for instance, depending on whether the sensation is based directly on the physical contact between the observer and the observed (as in the case of sensory and gustatory sensations), or on a distance between the objects (visual, auditory, and olfactory).

Typological studies conducted using the material of several languages argue that the main verbs of perception can form a three-level system in which each sensory area distinguishes an intransitive verb that expresses the general ability to perceive or "perceptibility"; a transitive, but non-agent verb that expresses sensory perception or "perception ability", and a transitive agent verb that also expresses sensory perception, but deliberately, purposefully using the ability to perceive [Viberg 1984, 2001; Huumo 2006].

Verbs of visual perception in the Erzya and Finnish languages, which are the subject of this study, reflect one of the most important types of human's perceptual activity - the perception of the surrounding world by the visual organs. Considering the hierarchical classification of the verbs that indicates the subject's ability to perceive the world, in the Erzya language the three-tier (level) system of verbs of vision appears as follows: неявомс 'be seen, be visible' (intransitive verb that expresses general ability to perceive) неемс 'to see, to get to see' (transitive non-agent verb pointing to nonpurposefulness of perception) ваномс 'to look, to watch, to turn eyes on' (transitive agent verb, pointing to the purposefulness of perception):

1. Промзань кудосо неявсь тол. [Korp] 'Fire was seen in Promza's house'.

2. Пирявкс ды вишка ортыне, конань томбальде неяви велень ульиясь. [Korp] 'There is a fence and a small gate, beyond which a rural street can be seen'.

3. - Мезть кевкстнят, или а неят, кодамо мон бояравась? [Korp] 'Why are you asking, don't you see, what kind of a noblewoman I am?'

4. Леенть велькссэ сон неизе пиземе чирькенть. [Korp] 'Over the river he saw a rainbow'.

5. Промза ваны валдо тештнень пелев ды яла арси. [Korp] 'Promza looks at bright stars and continues pondering'.

6. Теине конянзо алдо вансть полгаря тюжа сельмть. [Korp] 'His bulging brown eyes looked out from under his narrow forehead'.

In the Finnish language, visual perception verbs and their semantic-word formative derivatives form the following three-level system: näkyä 'be seen, be visible' $\sim$ nähd $\ddot{\boldsymbol{a}}$ 'to see, to get to see' $\sim \boldsymbol{k a t s o a}$ 'to look, to watch' (derivatives katsahtaa 'to have a look', katsastaa 'to see over, to see around', katsella 'to look through, to look over').

1. Heille näkyy nyt kaksi kanavaa, ja minä toivoisin, että me suomalaiset saisimme nyt edes yhden kanavan. [Korp] 'They can see two channels now, and I would hope that we Finns would now have even one channel'. 
2. Huoli näkyy tarkistuksessa, jota esittelijä McNally edelleen vaatii. [Korp] 'This concern is seen in the amendment that Mr McNally still insists on'.

3. Näin lehdestä, että olet mennyt kihloihin. [Korp] 'I saw in the magazine that you are engaged'.

4. Sa olet nähnyt hänet heikkona, sit' ei hän koskaan sulle anteeks anna. [Korp] 'You've seen him weak, but he'll never forgive you'.

5. Kun katsoin niitä, en nähnyt niissä mitään ongelmia. [Korp] 'When I looked at them, I didn't see any problems with them'.

6. He katsoivat minua ihmeissään, sillä he eivät ymmärtäneet kysymystäni. [Korp] 'They looked at me in amazement as they did not understand my question'.

The presented verbs have semantic and word formative derivatives. In the Erzya language derivatives of неявомс are such lexemes as неявкиномс 'be seen, be visible, to seem (repeatedness)', неезевемс 'to appear, to arise, to emerge (inchoativeness)'; неемс has неевтемс 'to show (causativeness)', не(е)кшнемс 'to see (repeatedness)', не(е)кшневемс 'be seen, be visible (possibility, reflectiveness)'; ваномс has вановомс 'to look, to look at oneself (possibility, reflectiveness)', ван(о)кшномс 'to look from time to time, to see over (repeatedness)', вановтомс 'to make smb. look at/ to make smb. be examined (causativeness)'. They bring to the verbs of vision shades of repeatedness, inchoativeness, causativeness, reflexiveness, possibility, and other meanings that can be characterized as quantitativetemporal, verbal aspect, voice, as well as special characteristics of achieving the result of an action:

1. Куш сэрьс апокшке, ве ёндо натой моцтемекс неявкиныль-ялатеке истямо важодиия костояк а муят. [MokshEr] 'Although not tall in size, he seemed powerless from the side, but still you will not find such an employee anywhere'.

2. Поесь свал монень неявкины од довакс. [MokshEr] 'Aspen is always seen to me as a young widow'.

3. ...васолдо неяви-маряви Пензанть пельде Самаранть пелев поревть янокс: велькссэнзэ васня неезеви ютыия поездэнть качамнезэ, мейле маряви гайтезэ, мейле лиси икелеть сонськак. [MokshEr] '...from far away the beaten track from Penza to Samara could be seen: first, smoke of a passing train appeared above it, then its sound was heard, then it appeared itself'.

4. Ошонь цёратне, кода сеедьстэ некшнесь Галя, седе наянт, а сонзэ кондят. [MokshEr] 'City boys, as Galya often saw, are more impudent, not like him'.

5. Минек велесь срадсь пакся куншкас, а касыть перьканзо вирть, а чуди малаванзо поки ведь, а некини морят-кораблят. [MokshEr] 'Our village is located among fields, forests do not grow around it, large water does not flow nearby, it does not see sea-ships'.

6. - Весе эрямось - бороиямо, - мерсь вейке рузонь поэт, - сэтьмечись некиневи ансяк онстот. [MokshEr] 'All life is a struggle, said a Russian poet, peace can be seen only in a dream'.

7. Тон, Дарё, меельие шкасто мекс-бути овсе ёмить, косояк а некшневат. [MokshEr] 'You, Daria, have recently completely disappeared for some reason, you can't be seen anywhere'.

8. Кие важоди колхозсо - весень вановтомс врачтнэнь кедьстэ! - вачкодсь прявтонок столь ланга. [MokshEr] 'Those who work on the collective farm - make everyone get examined by doctors - our manager hit the table'.

9. - Шумбрат, - проводницась ванкинызе иееранть прясто пильгс ды поладсь: - Невтик билетэть! [Korp] '- Hello, the conductor saw over the guy from head to toe and added: Show me your ticket'.

10. Колмоче ёвтнемасонть - «Авань сёрма» - сон неень шкань эрямонть лувсо ванкшны ававттнэнь ды урьватнень ладявомаст, вейке-вейкенень а шождасто самост. [MokshEr] 'In the third story - "The Letter of a Woman" - from the standpoint of modern life, he sees over the relations of mothers-in-law and daughters-in-law, their difficult rapprochement with each other'.

In the Finnish language, derivatives are found only for the transitive agent verb katsoa 'to look': katsahtaa 'to have a look (semelfactive)', katsastaa 'to see over, to see around, to check', katsella 'to look, to watch, to see over (continuous)', for instance:

1. Silloin Maija vetäysi ihmeissään syrjemmäs ja he katsahtivat ensi kerran toisiansa silmästä silmään. [Korp] 'Then, in amazement, Maija pulled away, and for the first time they had a look at each other face to face'. 
2. Hän katsahti ylös ja näki että mehiläiset parveilivat. [Korp] 'He had a look upwards and saw the bees swarming'.

3. Hiihtäjiä katsastettiin kilpailuissa Vuokatilla. [Korp] 'Skiers were checked in competitions in Vuokatti'.

4. Niin, minä katsastin ruokakomeron ja vintin ja kellarin ja navetan ja puutarhan, ja Fredrikssonkin sai luvan seurata mukana. [Korp] 'Yeah, I saw over/ checked the pantry and the attic and the basement and the barn and the garden and Fredriksson got permission to accompany me'.

5. Hän katseli minua ovella päästä jalkoihin. [Korp] 'He was looking at me in the door from head to toe'.

6. Hän seisahutti ja katseli meitä hymyillen. [Korp] 'He stopped and looked at us with a smile'

From a syntactic point of view, visual perception verbs in both Erzya and Finnish are clearly divided into two groups, intransitive (erz. неявомс 'be seen' and fin. näky ̈̈ 'be seen, to come into view') and transitive (erz. неемс 'to see, to get to see', ваномс 'to look, to turn eyes on' and fin. nähdä 'to see, to get to see', katsoa 'to look, watch'), which in turn are divided into agent (erz. ваномс 'to look, to turn eyes on', fin. katsoa 'to look, to watch') and non-agent (erz. неeмc 'to see, to get to see', fin. nähdä 'to see, to get to see').

From a semantic point of view, it can be noted that intransitive verbs of perception and transitive non-agent verbs are similar to each other, since both express the non-purposefulness of the process of perception, in which the percipient or the subject of perception plays an exclusive role of an observer. The difference, of course, is that with intransitive verbs, the perceiving subject remains implicit, i.e. there is no agent in such verbs, but it is implied [Huumo 2006]. Transitive verbs that express a deliberate ability to perceive, being agent verbs, denote an action aimed at making the sensory organ act on a specific object to detect it. Therefore, the subject at these verbs is considered as an agent.

1. Intransitive verbs erz. неявомс 'be seen' and fin. näkÿ̈ 'be seen, to come into view': Тикшенть nотсто сон эль неяви. [Korp] 'From under the hay it is barely seen'; Se näkyi myös neuvoston vastauksista. [Korp] 'It was also seen in the Council's replies'.

2. Transitive non-agent verbs erz. неемс 'to see, to get to see', fin. nähdä 'to see, to get to see': Шкань ютазь несь тейтерь, кона эйстэнзэ кекшнесь чувто экшс. [Korp] 'After a while, he saw a girl, who was hiding from him behind a tree'; Esitän syvät surunvalitteluni Stephen Saundersin vaimolle ja lapsille, jotka näimme televisiossa. [Korp] 'I extend my sincere condolences to Stephen Saunders' wife and children we got to see on television'.

3. Transitive agent verbs erz. ваномс 'to look, to turn eyes on', fin. katsoa 'to look, to watch': Истятнэнь лангс Михаил Алексеевич ваныль чирьстэ ды нулгодезь. [MokshEr] 'Mikhail Alekseevich looked at them askance and with disgust'; Huomaatte kyllä sen, mikäli katsotte uudestaan sääntöjä. [Korp] 'You notice this, of course, if you look at the rules again'.

In addition to the above, visual perception in the Erzya and Finnish languages can be conveyed by many other verbal units, directly or indirectly. The verbs closest in meaning to the main verbs of perception are those that describe the impression made by the perception, or the conclusion deduced by the subject of perception. Those in the Erzya language are the verbs невтемс 'to show, to point to; to look like' (derivatives невтнемс 'to show (repeatedness)', невтекинемс 'to show (repeatedness)', невтевемс 'to appear, to come into view (possibility, reflexiveness)', невтезевемс 'to appear (inchoative)'; варитамс 'to see over, to have a look' (derivatives варитнемс 'to have a look from time to time, to look in on (repeatedness)', варштакшномс 'to look after, to go and see (repeatedness)', варштавомс 'to look back (possibility, reflexiveness)', варштазевемс 'to look back (inchoative)', варитавтомс 'to make smb. look back' (causativeness), ванномс 'to see over, to explore', ванстнемс 'to look after, to see around'. In Finnish, you can mark out the verb näyttä̈̈ 'to look like, to seem; to show, to indicate' (derivatives näyttäytyä 'to appear, to come into view', näytellä 'to play, to show'): Вана кода невтеви произведениясонть те таркась. [MokshEr] 'This is how this place appears in the work'; Мейле, ламо иень ютазь, Вена невтекинизе кедензэ: сивезь таркасонть сон кичкерель. [Korp] 'Then, after many years, Vena showed his hand: in a broken place it was crooked'; Пургаз варштась ёнонзо. [Korp] 'Purgaz had a look at his direction'; Валскестэнть 
Пургаз ваннызе ошонть. [Korp] 'In the morning Purgaz saw over the city'; Варитавинь атянть лангс. [MokshEr] 'I looked back at my father'; Эx, Сёмка, Сёмка, нать, газетас тунь а варитнят. [MokshEr] 'Eh, Semka, Semka, so you don't look at the newspaper at all'.

These verbs are of particular interest for comparison: erz. невтемс 'to indicate, to show', and fin. näyttä̈ 'to show, to indicate; to look like, to appear'. Based on the meanings given in the dictionary 'to indicate, to show, to reveal', the Erzyan verb невтемс performs the function of a transitive verb [ERD]: Эзь иидярдо Таня, невтизе сёрманть Митянень. [Korp] 'Tanya could not stand it, showed a letter to Mitya'; Мон, мельсэть ашти, натой нарошной невтия тешксэнзэ. [Korp] 'I, if уоu remember, even specially showed his sign'.

Moreover, the Finnish verb näyttä̈̈, based on its semantics, acts both as a transitive one 'representation of the object of perception to the subject of perception', and as an intransitive one 'description of the impression created by sensory perception' [KTS]: Se on totta, hyvä Posselt, näytän teille valiokuntani esityslistan. [Korp] 'That is true, Mr Posselt, I will show you the agenda of my committee'; Muualla tämä on luonnollista, mutta näyttää siltä, että komissioon sovellettuna se on erittäin mullistava ehdotus. (Korp) 'Elsewhere, this is natural, but it appears as a very revolutionary proposal for the Commission'.

However, an in-depth analysis of the semantics of the Erzyan verb невтемс has shown that it can also act as an intransitive verb and convey the meaning 'to look like, to seem, to appear', for instance: Мирденть самодо мейле, алуж, седеяк ёнсто невтят, - пшкадсь Карияйкин. [Korp] 'After the husband's arrival, friend, you look even better, - said Kartsyaykin'; Сон невти нусманясто. (MokshEr) 'Не appears gloomy'; Куш тосонь [Япониянь] тейтерь-аватне мазыйть ды свал невтить одсто, ялатеке сынь арсить икельдямс весень ды анокстасть од йогурт. (Когр) 'Although the [Japanese] women there are beautiful and always look young, they still try to get ahead of everyone and have made a new cosmetic product'.

\section{Summary and Conclusions}

The study of a group of perception verbs with the semantics "visual perception" in the Erzya and Finnish languages has allowed us to achieve our goals, that is:

1) to present visual perception verbs as a three-level system based on the method of typological analysis;

2) to describe the structure of the semantic field of visual perception verbs drawing on the material from the Erzya and Finnish languages;

3 ) to identify the basic (nuclear) lexeme and reveal the peripheral lexemes of the represented field in both languages;

4) to analyze the system of meanings of nuclear and peripheral verbs of vision, based on definitions from explanatory dictionaries of the Erzya and Finnish languages, with the involvement of material from the linguistic corpora;

5) by using the method of comparative analysis to reveal additional semantic connotations of verbs that were not previously entered in dictionaries.

Therefore, in terms of word-formation, it can be argued that transitive non-agent verbs of perception are a kind of basic group, morphologically and perhaps also semantically, a category of sensory verbs without defining characteristics. From the point of view of semantics, these verbs occupy an intermediate position between intransitive and transitive agent verbs of perception, since they have common characteristics of both: with intransitive verbs, they are united by the absence of agentivity, and with transitive verbs, by the fact that two participants are possible in their structure: the object of perception (perceived) and the subject of perception (percipient).

The situation described by visual perception verbs requires (at least) two participants: the object of perception (perceived) and the subject of perception (percipient). Although only the object of perception is involved in the case of intransitive verbs, their meaning contains the subject of perception implicitly. In this case, the percipient will remain impersonal in principle, although it can be interpreted as a participant in a speech situation from the context. 

ABBREVIATION:
ERD - Erzyan-Russian Dictionary
KTS - Kielitoimiston sanakirja
erz. - the Erzya-Mordvin language
fin. - the Finnish language

\section{REFERENCES}

Arkhipova Yu. Yu. Sostav, semantika i funktsionirovanie leksiko-semanticheskoi gruppy glagolov zritel'nogo vospriyatiya (na materiale khudozhestvennykh tekstov): Avtoref. dis. kand. filol. nauk. [Composition, semantics and functioning of the lexical-semantic group of verbs of visual perception (based on the material of literary texts). Extended abstract of Cand. Philol. sci. diss.]. Saint-Petersburg, 2000. 22 p. In Russian.

Budantseva N. A. Glagol'naya taksonomicheskaya model' kontsepta zritel'noe vospriyatie (na materiale angliiskogo i frantsuzskogo yazykov): Avtoref. dis. kand. filol. nauk. [The verbal taxonomic model of the concept of visual perception (based on English and French). Extended abstract of Cand. Philol. sci. diss.]. Tambov, 2014. 18 p. In Russian.

Vasil'ev L. M. Semantika russkogo glagola. [Semantics of the Russian verb]. Moscow: Vysshaya shkola, 1981. 184 p. In Russian.

Gak V. G. Prostranstvo mysli (opyt sistematizatsii slov mental'nogo polya) [The space of thought (the experience of systematizing the words of the mental field)]. Logicheskii analiz yazyka. Mental'nye deistviya. [Logical analysis of the language. Mental actions]. Moscow: Nauka, 1993. Pp. 22-29. In Russian.

Garipova I. D. Slovoobrazovatel'naya determinatsiya glagolov zritel'nogo vospriyatiya (na materiale russkogo i tatarskogo yazykov): Avtoref. dis. kand. filol. nauk. [Word-formation determination of verbs of visual perception (based on the material of the Russian and Tatar languages). Extended abstract of Cand. Philol. sci. diss.]. Kazan, 2013. 22 p. In Russian.

Glinka E. V. Sistema glagolov vospriyatiya, myshleniya i govoreniya (na materiale istoricheskikh slovarei russkogo yazyka): Avtoref. dis. kand. filol. nauk. [The system of verbs of perception, thinking and speaking (based on the material of historical dictionaries of the Russian language). Extended abstract of Cand. Philol. sci. diss.]. Orel, 2003. 22 p. In Russian.

Kaksin A. D., Chertykova M. D. $K$ voprosu o glagolakh vospriyatiya $v$ khantyiskom yazyke [On the question of verbs of perception in the Khanty language]. Materialy VI Kongressa etnografov $i$ antropologov Rossii [Materials of the VI Congress of Ethnographers and Anthropologists of Russia]. Saint-Petersburg, 2005, P. 473. In Russian.

Kaksin A. D., Chertykova M. D. Kognitivnaya osnova semanticheskoi klassifikatsii glagolov vospriyatiya $v$ raznostrukturnykh yazykakh [Cognitive basis of the semantic classification of verbs of perception in different structural languages]. Kul'tura narodov Prichernomor'ya. Nauchnyi zhurnal [Culture of the peoples of the Black Sea. Scientific journal], 2009. Vol. 168. No. 1. Pp. 331-334. In Russian.

Karandashova N. E. Sinonimicheskie ryady glagolov psikhicheskoi deyatel'nosti: funktsional'no-semanticheskii aspekt: Dis. kand. filol. nauk. [Synonymous series of verbs of mental activity: a functional-semantic aspect. Cand. Philol. sci. diss.]. Saint-Petersburg, 2003. 209 p. In Russian.

Kozmach I. O tipologicheskoi klassifikatsii glagolov dvizheniya $v$ finno-ugorskikh yazykakh [On the typological classification of verbs of movement in the Finno-Ugric languages]. Ezhegodnik finno-ugorskikh issledovanii [Yearbook of Finno-Ugric Studies], 2020. Vol. 14. No 2. Pp. 222-226. In Russian.

Kubryakova E. S. Semantika v kognitivnoi lingvistike (o kontsepte konteinera i formakh ego ob"ektivatsii $v$ yazyke) [Semantics in cognitive linguistics (on the concept of the container and the forms of its objectification in the language)]. Izvestiya RAN. Seriya literatury i yazyka [The Bulletin of Russian Academy of Sciences: Studies of Literature and Language], 1999. Vol. 58. No. 5-6. Pp. 3-12. In Russian.

Kubryakova E. S. Yazyk i znanie: na puti polucheniya znanii o yazyke: chasti rechi s kognit. tochki zreniya. Rol' yazyka v poznanii mira [Language and knowledge: on the way to gain knowledge of the language: parts of speech from a cognitive point of view. The role of language in the knowledge of the world]. Moscow: Yazyki slavyanskoy kul'tury. 2004. 555 p. In Russian. 
Kubryakova E. S., Dem'yanenko V. Z., Pankrats Yu. G., Luzina L. G. Kratkii slovar' kognitivnykh terminov [A Brief Dictionary of Cognitive Terms]. Moscow: Moscow State University, 1997. 245 p. In Russian.

Moiseeva S. A. Semanticheskoe pole vospriyatiya v zapadno-romanskikh yazykakh: monografiya [Semantic field of perception in the West Romance languages. Monograph]. Belgorod, 2005. 258 p. In Russian.

Mosina N. M. Semantika glubinnykh padezhei i morfologicheskie sredstva ikh vyrazheniya v erzyanskom yazyke: Dis. dok. filol. nauk. [Semantics of deep cases and morphological means of their expression in the Erzya language. Dr. Philol. sci. diss.], Saransk, Izd-vo Mordov gos. un-ta, 2014. 231 p. In Russian.

Mosina N. M. Semantika glagolov mental'nogo deistviya v erzyanskom i finskom yazykakh [Semantics of verbs of mental action in the Erzya and Finnish languages]. VI Vserossiiskaya konferentsiya finno-ugrovedov "Finno-ugorskii mir v polietnichnom prostranstve Rossii: kul'turnoe nasledie i novye vyzovy" : [Materials of the VI All-Russian conference of Finno-Ugric scholars "Finno-Ugric world in the multi-ethnic space of Russia: cultural heritage and new challenges"]. Izhevsk, 2019. Pp. 106-111 p. In Russian.

Naisser U. Poznanie i real'nost'. Smysl i printsipy kognitivnoi psikhologii [Cognition and reality. The meaning and principles of cognitive psychology]. Moscow: Progress. 1981. 231 p. In Russian.

Peshkovskii A. M. Russkii sintaksis v nauchnom osveshchenii: zritel'noe vospriyatie + znanie. [Russian syntax in scientific coverage: visual perception + knowledge]. Moscow: Gos. uchebno-pedagogicheskoe izd-vo Ministerstva prosveshcheniya RSFSR, 1956. 512 p. In Russian.

Prokhorova O. N. Mental'nye struktury $i$ ikh reprezentatsiya leksicheskimi sredstvami $v$ germanskikh $i$ romanskikh yazykakh: monografiya [Mental structures and their representation by lexical means in Germanic and Romance languages. Monograph]. Moscow: Flinta, 2013. 332 p. In Russian.

Rubinshtein S. L. Bytie $i$ soznanie. O meste psikhicheskogo vo vseobshchei vzaimosvyazi yavlenii material'nogo mira : monografiya [Being and consciousness. On the place of the psychic in the universal interconnection of the phenomena of the material world. Monograph]. Moscow: Izd-vo Akad. nauk SSSR, 1957. 328 p. In Russian.

Cheif U. Pamyat' $i$ verbalizatsiya proshlogo opyta [Memory and verbalization of past experience] Novoe $v$ zarubezhnoi lingvistike. Prikladnaya lingvistika [New in foreign linguistics. Applied Linguistics], Moscow: Progress. 1983. Issue 12. Pp. 35-74. In Russian.

ERD - Erzyan'-ruzon' valks. Erzyansko-russkii slovar' [Erzya-Russian Dictionary]. Moscow: Russkii yazyk, Digora, 1993. 830 p. In Russian.

Yakubova V. G. Glagoly chuvstv v sovremennom russkom yazyke (Istoriya i funktsionirovanie): Dis. kand. filol. nauk. [Verbs of feelings in modern Russian (History and functioning). Cand. Philol. sci. diss.]. Moscow, 1988. 273 p. In Russian.

Huumo T. Näkökulmia suomen kielen aistihavaintoverbeihin. Emakeele Seltsi aastaraamat, № 52. 2006. S. 69-86. In Finnish.

Huumo T. Kognition kieli: miten suomen kieli käsitteistää aistihavainnon // Sananjalka, № 47. 2005. Turku, S. 7-41. In Finnish.

KORP. Suomen kielipankki. The Concordance Search Tool. URL: https://korp.csc.fi/. In Finnish. (accessed 15 December 2020).

KTS - Kielitoimiston sanakirja. Helsinki: Kotimaisten kielten keskuksen verkkojulkaisuja 35, 2020. The Concordance Search Tool. URL: https://www.kielitoimistonsanakirja.fi. In Finnish. (accessed 10 December 2020).

MokshEr. Moksha, Erzya electronic corpus, version 3, CD ROM. Turku, 2010.

Viberg Å. The verbs of perception: A typological study. Linguistics, 1984. Vol. 21. Pp. 123-163.

Viberg Å. Verbs of perception. Language typology and linguistic universals. Vol. 2. Berlin: Walter de Gruyter, 2001. Pp. 1249-1309. 
Mosina Natalya Michailovna, Doctor of Philology, Professor,

National Research Ogarev Mordovia State University 68/1, Bolshevistskaya st., Saransk, 430005, Russian Federation. e-mail: natamish@rambler.ru

Kazaeva Nina Valentinovna, Candidate of Philology, Associate Professor, National Research Ogarev Mordovia State University 68/1, Bolshevistskaya st., Saransk, 430005, Russian Federation. e-mail: nikazaeva@yandex.ru

\title{
Н. М. Мосина, Н. В. Казаева \\ СЕМАНТИКА ГЛАГОЛОВ ЗРИТЕЛЬНОГО ВОСПРИЯТИЯ В ЭРЗЯ-МОРДОВСКОМ И ФИНСКОМ ЯЗЫКАХ
}

\author{
DOI: $10.35634 / 2224-9443-2021-15-1-23-33$
}

Предметом изучения в данной статье явились глаголы зрительного восприятия в эрзя-мордовском и финском языках с точки зрения их семантических характеристик в сравнительном плане. Глаголы зрительного восприятия образуют отдельную подгруппу и относятся к многокомпонентной группе глаголов чувственного восприятия. В зависимости от ведущей роли сенсорной системы, которая играет главную роль в восприятии, наряду со зрительными различают слуховые, осязательные, обонятельные и вкусовые типы восприятия. Данная группа глаголов имеет нравственный уровень соотношений: будучи глаголами восприятия, они направлены на объекты, имеющие физические характеристики, однако многие из них, являясь глаголами не только физического, но и чувственного восприятия, ориентированы на восприятие понятий. В связи с этим глаголы чувственного восприятия развивают многозначность, которая идет в разных направлениях.

Новизна исследования заключается в исследовании лексического уровня эрзя-мордовского и финского языков в сравнительном плане, что позволит в дальнейшем решить отдельные вопросы финно-угорского языкознания. Проблема, связанная с изучением семантики глаголов восприятия, или перцептивной деятельности, является весьма актуальной. Отсутствие специальных работ о глаголах восприятия на материале мордовских языков, а также недостаточная их изученность в сравнительном плане ущербно сказывается на разработке лексикологии, словообразования финно-угорских языков.

В связи с этим целью данного исследования является необходимость описать структуру семантического поля глаголов одного аспекта восприятия, а именно - зрительного; определить ядерные и периферийные глагольные единицы на материале исследуемых языков; описать систему значений глагольных лексем в эрзянском и финском языках; проанализировать многозначность исследуемой группы глаголов в каждом из представленных языков; выявить дополнительные семантические оттенки у глагольных лексем. Особый интерес вызывает также сравнительное изучение особенностей проявления одного и того же семантического значения на материале дальнородственных языков, в данном случае - эрзянского и финского. Материалом для исследования послужили глагольные единицы, обладающие общей семантикой зрительного восприятия в современных эрзянском и финском языках, рассмотренные с помощью описательного, компонентного и сравнительного методов анализа.

Ключевые слова: глаголы зрительного восприятия, семантика, сравнительный анализ, эрзянский язык, финский язык.

Citation: Yearbook of Finno-Ugric Studies, 2021, vol. 15, issue 1, pp. 23-33. In English. 


\section{ЛИТЕРАТУРА:}

Архипова Ю. Ю. Состав, семантика и функционирование лексико-семантической группы глаголов зрительного восприятия (на материале художественных текстов): автореф. дис. ... канд. филол. наук. СПб., 2000. 22 с.

Буданцева Н. А. Глагольная таксономическая модель концепта зрительное восприятие (на материале английского и французского языков): автореф. дис... канд. филол. наук. Тамбов, 2014. 18 с.

Васильев Л. М. Семантика русского глагола. М. : Высш. шк., 1981. 184 с.

Гак В. Г. Пространство мысли (опыт систематизации слов ментального поля) // Логический анализ языка. Ментальные действия. М.: Наука, 1993. 396 с.

Гарипова И. Д. Словообразовательная детерминация глаголов зрительного восприятия (на материале русского и татарского языков): автореф. дис. ... канд. филол. наук. Казань, 2013. 22 с.

Глинка E. В. Система глаголов восприятия, мышления и говорения (на материале исторических словарей русского языка): автореф. дис. ... канд. филол. наук. Орел, 2003. 22 с.

Каксин А. Д., Чертыкова М. Д. К вопросу о глаголах восприятия в хантыйском языке // Материалы VI Конгресса этнографов и антропологов России (Санкт-Петербург, 28 июня - 2 июля 2005 г.). СПб., 2005. C. 473.

Каксин А. Д., Чертылкова М. Д. Когнитивная основа семантической классификации глаголов восприятия в разноструктурных языках // Культура народов Причерноморья. Научный журнал. 2009. № 168. T. 1. C. 331-334.

Карандашова Н. Э. Синонимические ряды глаголов психической деятельности: функциональносемантический аспект : дис. ... канд. филол. наук. СПб., 2003. 209 с.

Козмач И. О типологической классификации глаголов движения в финно-угорских языках // Ежегодник финно-угорских исследований. 2020. Т. 14. № 2. С. 222-226.

Кубрякова E. С. Семантика в когнитивной лингвистике (о концепте контейнера и формах его объективации в языке) // Известия РАН. Серия литературы и языка. Т. 58. № 5-6. 1999. С. 3-12.

Кубрякова E. C. Язык и знание : на пути получения знаний о языке: части речи с когнит. точки зрения. Роль языка в познании мира; Ин-т языкознания РАН. М. : Яз. славян. культуры, 2004. 555 с.

Кубрякова Е. С., Демьяненко В. З., Панкраи Ю. Г., Лузина Л. Г. Краткий словарь когнитивных терминов. М.: МГУ, 1997. 245 с.

Моисеева С. А. Семантическое поле восприятия в западно-романских языках: монография. Белгород, 2005. $258 \mathrm{c}$.

Мосина Н. М. Семантика глубинных падежей и морфологические средства их выражения в эрзянском языке: дис. ... д-ра филол. наук. Мордов. гос. ун-т. Саранск, 2014. 231 с.

Мосина Н. М. Семантика глаголов ментального действия в эрзянском и финском языках // VI Bceроссийская конференция финно-угроведов «Финно-угорский мир в полиэтничном пространстве России: культурное наследие и новые вызовы»: материалы / Редкол.: Л. Н. Бехтерева, Н. В. Кондратьева и др. Ижевск, 2019. С. 106-111.

Найссер У. Познание и реальность. Смысл и принципы когнитивной психологии. М.: Прогресс, 1981. $231 \mathrm{c}$.

Пешковский А. М. Русский синтаксис в научном освещении: зрительное восприятие + знание. М.: Гос. учебно-педагогическое изд-во Министерства просвещения РСФСР, 1956. 512 с.

Прохорова О. Н. Ментальные структуры и их репрезентация лексическими средствами в германских и романских языках: монография. 2-ое изд. М.: Флинта, 2013. 332 с.

Рубинштейн С. Л. Бытие и сознание. О месте психического во всеобщей взаимосвязи явлений материального мира: монография. М.: Изд-во Акад. наук СССР, 1957. 328 с.

Чейф У. Память и вербализация прошлого опыта // Новое в зарубежной лингвистике. Прикладная лингвистика. М.: Прогресс, 1983. Вып.12. С. 35-74.

Эрзянь-рузонь валкс. Эрзянско-русский словарь. М.: Рус. яз., 1993. 830 с.

Якубова В. Г. Глаголы чувств в современном русском языке (История и функционирование): дис. ... канд. филол. наук. М., 1988. 273 с. 
Huито T. Näkökulmia suomen kielen aistihavaintoverbeihin // Emakeele Seltsi Aastaraamat. 2006. №52. S. 69-86.

Huито T. Kognition kieli: miten suomen kieli käsitteistää aistihavainnon // Sananjalka. 2005. № 47. Turku. S. 7-41.

KORP. Suomen kielipankki. Режим доступа: https://korp.csc.fi/. (дата обращения: 15.12.2020).

Kielitoimiston sanakirja. Helsinki: Kotimaisten kielten keskuksen verkkojulkaisuja 35, 2020. Режим доступа: https://www.kielitoimistonsanakirja.fi. (дата обращения: 10.12.2020).

MokshEr. Электронный корпус мокшанского и эрзянского языков, версия 3. CD ROM. Turku, 2010.

Viberg $A$. The verbs of perception: A typological study. Linguistics 21, 1984. Pp. 123-163.

Viberg $A$. Verbs of perception. Language typology and linguistic universals. Vol. 2. Ed. by Martin Haspelmath, Ekkehard König, Wulf Oesterreicher, Wolfgang Raible. Berlin: Walter de Gruyter, 2001. Pp. 1249-1309.

Поступила в редакцию 09.12.2020

Мосина Наталья Михайловна, доктор филологических наук, профессор, ФГБОУ ВО «Национальный исследовательский Мордовский государственный университет имени Н. П. Огарёва» 430005, Россия, г. Саранск, ул. Большевистская, д. 68/1 e-mail: natamish@rambler.ru

Казаева Нина Валентиновна, кандидат филологических наук, доцент, ФГБОУ ВО «Национальный исследовательский Мордовский государственный университет имени Н. П. Огарёва» 430005, Россия, г. Саранск, ул. Большевистская, д. 68/1 e-mail: nikazaeva@yandex.ru 